\title{
Czcij (...), abyś długo żył na ziemi. O czwartym przykazaniu z myślą o podręcznikach i lekcjach języka polskiego
}

\author{
Honour (...) that you may live long on earth. On the \\ Fourth Commandment for Textbooks and Polish \\ Language Lessons
}

\author{
Kordian Bakuła \\ Uniwersytet Wrocławski \\ ORCID: 0000-0002-4049-846X
}

\begin{abstract}
The article aims to show the tension between the Old Testament, which is religiously motivated honour thy father and thy mother, and the modern version, which is earthly, human, respect the father and mother, respect the parents. The way to achieve this will be through didactic activities that expand the field of knowledge: reading the full versions of the fourth commandment; to know the terrible penalties that threaten to be imposed for the misconduct of honor of parents; recalling scenes of child sacrifice; reading Polish interpretations of the Fourth Commandment by M. Rej and E. Gliczner. Conclusion: for us in our time, it is most appropriate to require the natural respect of children for parents - without any mediation of old religious beliefs.

Key words: teaching Polish language, literature and culture, Old Testament, the fourth commandment, obedience to one's parents, punishing children, outdated tradition

Streszczenie: Artykuł ma na celu pokazanie napięcia między starotestamentowym nakazem motywowanym religijnie czcij ojca swego i matkę swoja..., a współczesnym nam, ziemskim, ludzkim szanuj ojca i matkę, szanuj rodziców. Sposobem na osiągnięcie tego celu będą czynności dydaktyczne poszerzające pole wiedzy: przeczytanie pełnych wersji przykazania czwartego; poznanie strasznych kar grożących za uchybianie czci rodzicom; przywołanie scen składania ofiar z dzieci; czytanie polskich interpretacji czwartego przykazania przez M. Reja i E. Glicznera. Wniosek: dla nas na nasze czasy najbardziej odpowiednim jest wymaganie naturalnego szacunku dzieci dla rodziców - bez pośrednictwa dawnych religijnych mniemań.
\end{abstract}

Słowa kluczowe: kształcenie językowe, literackie i kulturalne, Stary Testament, czwarte przykazanie, posłuszeństwo, karanie dzieci, przebrzmiała tradycja

Oto od wieków po wielekroć powtarzane przykazanie, żeby czcić ojca swego i matkę swoją. I wzruszają się dzisiejsi ludzie szlachetnością tego nakazu, zgadzają się z nim, doceniają, a jednocześnie nieraz zapominają, że jest to wersja skrócona z właściwej, jaką zapisano w Starym Testamencie, w której, jeśli ją w całości przeczytają wraz z wynikającymi 
z niej konsekwencjami i zastanowią się nad nią, dostrzegą być może coś, czego się nie spodziewali i co być może sprzeciwia się ich poglądom na rodzinę i sposób bycia w rodzinie.

Obok wersji z czcij... istnieje również szanuj ojca i matkę lub szanuj rodziców. Zwykle czcij i szanuj wymienia się jednym tchem jako wyrazy bliskoznaczne, ale nazbyt pośpiesznie, bo tylko w niektórych użyciach czcij i szanuj pokrywają się. Czcij ma węższy zakres niż szanuj: szanuję czyjeś zdanie, zwyczaje, prawa, ale ich nie czczę, szanuję urząd prezydenta, ale nie czczę itp.; a także szanuję matkę, ale nie czczę, choć niewykluczone, że są dzieci czczące swoje matki. Czcij wymaga hołdu, wyraża dużą podległość, zresztą należy do zestawu religijnych nakazów i zakazów narzuconych wyznawcy z góry; z kolei szanuj jest religijnie nieokreślone, obojętne. Różnice między nimi pokazują upływ czasu, przemiany kultury i społeczeństwa, w tym uwalnianie się od sił „nadprzyrodzonych” (cudzysłów stąd, gdyż takie nie istnieją), laicyzowanie się. Sądzę, że między starożytnym zapisem, jego autorami i w ogóle światem starożytnym a światem dzisiejszym zachodzą zasadnicze różnice, często niedostrzegane i pomijane, przesłonięte bielmem pozorów bliskości. Część z tych różnic zostanie tu wskazana i scharakteryzowana. Przyjmuję jako punkt wyjścia pogląd - nadający się również do umieszczenia w punkcie dojścia - wyrażony już w 1923 roku przez Jana Hempla (Hempel 1956, 114):

Przykazanie czwarte - pochodzi z tych czasów zamierzchłych, kiedy władza ojca była najwyższą władzą społeczną i rozciągała się nie tylko na dzieci małoletnie, lecz także na dorosłych członków rodziny, którzy winni byli rodzicom posłuszeństwo bezwzględne. Dzisiaj poza wymaganiem naturalnego szacunku dzieci dla rodziców nie ma ono zgoła znaczenia poważniejszego.

Pisano o tym przykazaniu nie raz (np. Chouraqui 2002, Ravasi 2003, „Zeszyty Karmelitańskie” 2014, nr 2 w całości poświęcone przykazaniu czwartemu) dokładnie i szeroko, ale $\mathrm{w}$ dydaktyce, w podręcznikach, na lekcjach raczej wąsko, i z tego powodu płytko, konwencjonalnie, a nawet katechetycznie, niekiedy czyniąc tematem dość powszechne, choć nieprawdziwe przekonanie: Dekalog - najstarszy zbiór norm moralnych ${ }^{1}$. Z pewnością nie jest najstarszy i nie tylko norm moralnych. Jak na jeden temat za dużo błędów rzeczowych. Te wąskie ujęcia lub fałszywe mniemania, są powodem, jednym z wielu, by napisać artykuł o czwartym z przykazań i pokazać konieczne uzupełnienia, dopowiedzenia, rozszerzenia, konteksty, nawiązania, niektóre często przywoływane (zob. bibliografia), ale nie w podręcznikach i lekcjach.

${ }^{1}$ Lekcja w klasie 7 z marca 2020 roku http://wysoka.mojaszkola.net/images/2020/0325 zadania LJ\%C4\% 99zyk\% 20\%20polski\%20klasa\%20VII.pdf(dostęp 19.07.2021). Tu również pytanie: 2. Co należy robić, by postępować zgodnie z przykazaniem „Czcij ojca swego i matkę swoją”? Zadaje się też prace pisemne na lekcji lub do domu, np. https://www.bryk.pl/wypracowania/jezyk-polski/antyk-i-biblia/21959-jak-rozumiem-iv-przykazanie.html (dostęp19.07.2021); inne ćwiczenia zob. w materiałach dla nauczycieli wydanych przez GWO pt. Klucze do obrazów. Analiza i interpretacja dzieła sztuki na lekcjach języka polskiego i historii, 2014 i na nich oparta lekcja w kl. 7. https://gwo.pl/ klucze-do-obrazow-4-p4516 (dostęp 20.07.2021). 
Zgromadzone w Starym Testamencie biblia, księgi są ważne w kulturze polskiej i europejskiej, co oczywiste, choć nieoczywisty jest charakter, sposób, głębia i rozległość ich funkcjonowania; reprezentują dawność, więc kwestię stanowi ich miejsce w teraźniejszości - pozornie dobrze się w niej odnajdują, bezproblemowo, co właśnie okazuje się najbardziej problematyczne. W związku z tym podjęte zostaną w artykule rozważania dotyczące problemów poznawczych.

Pierwszą trudnością poznawczą jest ogólnospołeczna niedostateczna wiedza o przykazaniu, co wywodzę z ogólnospołecznej znajomości jedynie jego wersji najkrótszej; druga trudność poznawcza dotyczy nieznajomości otoczenia przykazania: obyczajów, moralności, prawa, o których pisze się w różnych miejscach Starego Testamentu; tę trudność można nazwać nieznajomością kontekstu, z czego wynika potrzeba jego przywołania, przeczytania; trzecia trudność poznawcza tkwi w przyzwyczajeniach myślowych i uczuciowych towarzyszących odbiorowi przykazania, hamujących chęć pokonania trudności.

Wbrew pozorom przykazanie czwarte nie jest łatwe ani proste. Nie wystarczy, gdy chcemy się nim zająć na lekcji, intuicyjne i sentymentalne zazwyczaj jego traktowanie. W ogóle Stary Testament stanowi poważną trudność dla dzisiejszego czytelnika, uważnego, myślącego. Takiemu czytelnikowi, nie zaś przypadkowemu czy leniwemu, proponuję postępowanie badawcze w kilku krokach, za każdym razem poszerzających pole widzenia, pole wiedzy: 1. krok: przeczytanie pełnych wersji przykazania czwartego; 2. krok: poznanie kar grożących za uchybianie czci rodzicom wymienionych w kilku różnych księgach Starego Testamentu; 3. krok: przywołanie scen składania ofiar; 4 . krok: nawiązania polskie. Te cztery kroki poznawcze złożą się na jedną lekcję.

\section{Całe przykazanie czwarte}

Powszechnie znana krótsza wersja Czcij ojca swego i matke swoja zwykle nie budzi zastrzeżeń, a raczej budzi zaufanie i uznanie. (Czyż nie dlatego tak się upowszechniła?) Słuchacz lub czytelnik chyba sam dopowiada, że chodzi o cześć dla ojca i matki ze względu na nich samych i ze względu na dobre stosunki między rodzicami a dziećmi. Kiedy jednak pozna się całe przykazanie, tak jak zostało zapisane po raz pierwszy w Księdze Wyjścia, to sprawa nie jest już tak prosta ani tak oczywista: 20,12. Czcij ojca swego i matkę swoja, aby długo trwały twoje dni w ziemi, która Pan, Bóg twój, da tobie. Pojawił się warunek dość niespodziewanie dotyczący nie rodziców, lecz tego, który ma cześć oddawać, aby on sam żył długo. Uprawniony będzie domysł, że w wypadku nieokazywania czci rodzicom życie syna, do którego skierowane jest przykazanie, może ulec skróceniu... Dalej w Księdze Powtórzonego Prawa znajduje się kolejny zapis, najbardziej rozbudowany: 5,16. Czcij ojca swego i matke twoja, jak ci rozkazał Pan, twój Bóg, aby 
długo trwały twoje dni i aby ci się dobrze działo w ziemi, która Pan, twój Bóg, ci daje. Nie mamy już do czynienia z prostym czcij ojca i matkę. Cała konstrukcja przykazania okazuje się dość złożona, wszystko zależne, uwarunkowane, nie tak jak zwykle się wydaje; dochodzą nowe treści, wiemy więcej, na czym polega, co znaczy, kto od czego zależy, kto o czym decyduje: jak ci rozkazał Pan. Za niewykonanie boskiego nakazu grożą poważne kary, o czym niżej.

W tym miejscu przydatne będzie uświadomienie sobie i dopowiedzenie jeszcze paru szczegółów. Czcij, dotyczące w całej Biblii najczęściej młodzieńca i dorosłego syna, przełóżmy na czyny i słowa, na przykład: nie złorzecz rodzicom, nie bluźnij, nie oczerniaj, nie donoś na nich, nie oskarżaj fałszywie, chwal, bądź dumny z nich, rozgłaszaj ich dobre imię, opiekuj się, utrzymuj, zaopatruj, karm zwłaszcza na starość, wreszcie pochowaj.

Konieczne będzie również uświadomienie sobie jeszcze kilku cech rodziny ówczesnej, do której przykazanie się odnosi. Powstawała ona w wyniku małżeństwa poligamicznego - innego w Starym Testamencie nie ma! (Jak w ogóle można, mówiąc o monogamii, powoływać się na Stary Testament, skoro w świecie $\mathrm{w}$ nim przedstawionym powszechnie panowało wielożeństwo i nałożnictwo!?) Na czele rodziny stał ojciec, jedynowładca, pan życia i śmierci dzieci, z pewnymi ograniczeniami władzy przez plemienne prawo, a naczelną zasadą tej rodziny, jak w całej Biblii, jest posłuszeństwo; oprócz ich matki (tej wymienionej w przykazaniu) są inne kobiety, żony, ich liczba zależała od zamożności mężczyzny; wreszcie ich dzieci, w tym syn, którego przykazanie dotyczy w pierwszej kolejności, jeśli nie wyłącznie, bo córka lub córki znajdowały się w cieniu, odsunięte; ten syn, młodzieniec lub już dorosły, zależny od ojca, pracujący u niego i dla niego, aby żyć i aby mieć za co kupić sobie żonę (kobietę, na początek przynajmniej jedną), z konieczności musi być posłuszny woli ojca; synowi nie tylko wbito do głowy czcij ojca i matkę, ale i żebyś długo żył, co pociąga za sobą i co zostało mu również wbite do głowy, aby zważał na słowa i uczynki wobec ojca i matki z powodu grożących mu kar, wiszących nad nim lub zrealizowanych, z których częsta była chłosta, nierzadkie wydziedziczenie, a zdarzała się kara śmierci.

\section{Kary za nieprzestrzeganie przykazania}

Przykazanie, wraz z całym zakonem, prawem, nie jest łatwe dzisiaj także $\mathrm{z}$ kolejnego powodu, jakim było surowe karanie dzieci. O ich losie rodzice decydowali bezwzględnie i wyłącznie, na co wskazują liczne nakazy, zakazy, groźby rozrzucone po różnych księgach: $Z$ całego serca czcij swego ojca, a boleści rodzicielki nie zapominaj! Pamiętaj, że oni cię zrodzili, a cóż im zwrócisz za to, co oni tobie dali? (Syr 7,27); każdy z was będzie miał bojaźń przed swa matkq i swym ojcem (Kpł 19,3). Posłuszeństwo rodzicom wymagane jest bodaj we wszystkich społeczeństwach, ale bojaźń już nie, w tym 
ta wymuszona karaniem, które w Starym Testamencie zwykle polegało na chłoście: Kto miłuje swego syna, często używa na niego rózgi, aby na końcu mógł się nim cieszyć (Syr 30,1-2); Rózga i karcenie daja mądrość, lecz nieposłuszny chłopiec przynosi wstyd swojej matce (Prz 29,15); Karć swojego syna, a oszczędzi ci niepokoju i sprawi rozkosz twojej duszy (Prz 29,17). Podobnie w Nowym Testamencie w listach Pawła: A wy, ojcowie, nie pobudzajcie do gniewu waszych dzieci, lecz wychowujcie je, stosujac karcenie i napominanie Pańskie! (Ef 6,4). Syn karany, bity i posłuszny nabywa szczególnej mądrości, w przeciwieństwie do krnąbrnego: Syn mądry miłuje karcenie, naśmiewca nie słucha nagany (Prz 13,1). W ogóle cała Europa chrześcijańska przez długie stulecia wyznawała pedagogiczny i społeczny pogląd wypracowany już w starożytności a zwięźle ujęty u nas w wyrażeniu przysłowiowym, że syn jest lepszy karany (Krzyżanowski 1960, 213-214; także niżej Gliczner).

To jeszcze nie wszystko, co przyda się do pogłębienia rozumienia przykazania, zdobycia wiedzy o świecie przedstawionym. Nie raz pojawiają się w Starym Testamencie przepisy, nakazy, które dają poznać okoliczności towarzyszące owemu czcij, pokazują skutki jego nieprzestrzegania przewidziane $\mathrm{w}$ prawie żydowskiego koczowniczego plemienia. W Księdze Powtórzonego Prawa napisano: 27,16. Przeklęty, kto zlekceważy swego ojca i matkę. A cały lud powie: Amen. Zrobiło się groźnie. Lekceważenie ojca i matki kończy się karą przekleństwa nałożoną, wygłoszoną przez kapłanów i potwierdzone, uznane przez lud. Przeklęte zostaje każde odstępstwo od zakonu. Skutki tych odstępstw, skutki nieposłuszeństwa są przedstawione dokładnie w kilkudziesięciu wersetach rozdziału 28,15 - 69 Księgi Powtórzonego Prawa czy w Księdze Przysłów, np. oko, które wyśmiewa ojca i gardzi matka staruszka, wydziobia kruki nad potokiem i wyjedza orlęta (Prz 30,17).

Winnego braku czci nie tylko przekleństwo czeka. Nie na tym się kończy władza Jahwe, a ściślej - władza plemienia i kapłanów. Są gorsze niż lekceważenie przestępstwa wobec ojca i matki i gorsza kara. Obrazowo przedstawiono ją w Księdze Przysłów: Kto przeklina swojego ojca i swoja matke, tego lampa z nastaniem ciemności gaśnie (Prz 20, 20). Rzeczowo zaś w prawie żydowskim, przewidującym ostre, ostateczne kary za uchybienia wobec rodziców. Kilkanaście wersów dalej po przykazaniu czwartym zapisano: 15. Kto uderzy ojca swego albo matkę swoja, poniesie śmierć. 17. Kto złorzeczy ojcu swemu albo matce swojej, poniesie śmierć (Wj, 21 oraz Kapł 20,9). Zrobiło się strasznie. Za przykazaniem czci dla ojca i matki stoi śmierć ich dzieci.

Pamiętając o wszystkim, co wyżej, teraz chyba z większą uwagą przeczytamy przykazanie w całości: 20,12. Czcij ojca swego i matke swoja, aby długo trwały twoje dni w ziemi, która Pan, Bóg twój, da tobie. Nie można przeoczyć drugiej części tego przykazania, ujawniającej jego właściwy, twardy sens. Cześć dla ojca i matki nie jest bezinteresowna, lecz 
konieczna, by długo żyć, dosłownie: przeżyć. Tylko wtedy, gdy syn będzie czcił ojca i matkę, przeżyje, w innym wypadku grozi mu to, że zginie, zostanie sprzedany jako niewolnik, zostanie wygnany $\mathrm{z}$ domu, a zdarzało się ukamienowanie. Taka była ówczesna rzeczywistość, co poświadczają odpowiednie wersety ze Starego Testamentu: ojciec mógł sprzedać córkę jako niewolnicę (Wj 21,7), przymusić ją do nierządu (Kpł 19,29), krnąbrnego syna doprowadzić do ukamienowania przy pomocy starszyzny miasta (Pwt 21,18-21), wierzyciel miał prawo odebrać dłużnikowi dzieci, wziąć jako niewolników za niespłacony dług $(2 \mathrm{Kpł} 4,1)$. Ten sens biologiczny, przetrwaniowy należy wychwycić w omawianym przykazaniu. Tu chodzi o życie, zupełnie zależne od plemiennego prawa: ...poniesie śmierć. (To przecież prawo zasadniczo odmienne od współczesnego nam, więc stale dziwię się, że tak wielu współczesnych ludzi odczuwa bliskość ze światem przedstawionym w tych księgach.)

Wszystkie przywołane sytuacje, zdarzenia wskazują na podrzędną, niekiedy służebną pozycję dzieci, całkowicie zależną, zwłaszcza od ojca. On decydował o powodzeniu, dobrobycie i życiu, przeżyciu, więc w ich interesie leżało, by nie lekceważyć, nie sprzeciwiać się rodzicom ani tym bardziej nastawać na nich. Niska pozycja dzieci pociąga za sobą uległość, pokorę i zwłaszcza posłuszeństwo, postawę kluczową dla Starego Testamentu, zresztą Nowego także. Na niej w dużej mierze opiera się czcij z czwartego przykazania.

Istniał więc cały zestaw działań, kar, jakimi rozporządzał Jahwe (w rzeczywistości kapłani i przywódcy), by wyznawcy byli posłuszni, spełniali wszystkie nakazy i zakazy. Za czwartym przykazaniem, jak za całym dekalogiem i innymi prawami, stoi Jahwe straszny i mściwy (zob. np. Pwt 28, 58-60), niepokazywany w podręcznikach do języka polskiego.

\section{Zabijanie dzieci, dzieci jako ofiary składane Jahwe}

Inne konteksty, tak pochodzące z różnych ksiąg Starego Testamentu, jak innych kultur, w tym wypadku greckiej, pokażą jeszcze jedną straszną sytuację dzieci.

Nieuniknionym kontekstem będzie opowiadanie o zamierzonym, lecz niezrealizowanym mordzie ofiarnym: Abraham przymierzał się do zabicia własnego syna ku czci Jahwe. Opowiadanie pokazuje ten okres, kiedy Żydzi odchodzą od zwyczaju składania pierworodnych synów na ofiarę, a w innych sytuacjach córki, jak uczynił Jefte². Aby sobie ułatwić zadanie, kapłani co pewien czas przeprowadzali spis pierworodnych synów. Groza wtedy ogarniała Palestynę. Choć groza może jest odczuciem właściwym naszym czasom; może rodzice żydowscy czuli się wyróżnieni, zaszczyceni wyborem - przecież ręka nie zadrżała Abrahamowi ani powieka. Ta historia

${ }^{2} \mathrm{O}$ tym nie tylko w Starym Testamencie, ale też w powieści Liona Feuchtwangera, Jefte i jego córka, 1957, wydanie polskie 1964, tu także o innych ofiarach z dzieci na terenie ówczesnej Palestyny.

Polonistyka. Innowacje

Numer 14, 2021 
jako kontekst dla omawianego przykazania zabarwia je na inny kolor niż miało do tej pory.

Ofiary z dzieci praktykowano w śródziemnomorskim kręgu, także w Grecji, o czym świadczy złożony w ofierze Posejdonowi syn Idomeneusa, króla Krety. Grecja, w której na długo przed księgami hebrajskimi znano i zapisano obowiązek czci dla rodziców, dostarcza kolejnego kontekstu. Niestety, nie ma podręcznika lub lekcji, gdzie by ten grecki kontekst dla tego lub innego przykazania, lub w ogóle wszelakich zagadnień starotestamentowych, uruchomiono.

\section{Przykazanie greckie}

O czci dla ojca i w ogóle starców, choćby wobec Nestora, nie raz wzmiankuje się w Iliadzie, np. Najbardziej ze starców go czcił Agamemnon (pieśń II, 21); Andromacha nazywa ojca i matkę czcigodnymi (pieśń VI, 429), Priam liczy, że Achilles wiek uszanuje podeszły (pieśń XXII, 419), co później podobnie brzmi w radzie Chilona (VI w. p.n.e.) Szanuj podeszły wiek (Laertios $1968,46)^{3}$. Prawo i grecka mądrość wyraziły się w przykazaniu Solona (VII/ VI w. p.n.e.) Czcij bogów, szanuj rodziców (Laertios 1968, 41), w przekonaniu Sokratesa i Hippiasza (V/IV w. p.n.e.), że nakaz poszanowania rodziców obowiązuje powszechnie na świecie ${ }^{4}$, słynnych greckich mędrców, znanych powszechnie, z których tylko jeden trafia do podręczników czy konspektów lub artykułów. Z czasem te dwa wyrazy, cześć i szacunek, się wyspecjalizowały i dziś w kulturze europejskiej rzecz tak wygląda - i słusznie - jak zwięźle i jasno ujął Solon. On również ustanowił karę dla dorosłych dzieci uchylających się od obowiązków wobec rodziców: Kto nie łoży na utrzymanie swoich rodziców, ma być pozbawiony praw obywatelskich (Laertios 1968, 38). Nie ustanowił jednak kary dla ojcobójców, a kiedy pytano go o przyczynę, odpowiedział, że „nie przypuszcza, aby taka zbrodnia miała się kiedykolwiek zdarzyć" (Laertios1968, 40). Jak wiadomo, także z literatury greckiej i mitów, ojcobójstwo się zdarzało; także matkobójstwo i dzieciobójstwo. Różnie jednak traktowano te zbrodnie. Ojcobójstwo i matkobójstwo uważali Grecy za najgorsze, potworne zbrodnie, co potwierdza wypowiedź Solona, ale dzieciobójstwo traktowali wyrozumiale ${ }^{5}$. Więc i u Greków dzieci miały się czego bać, zwłaszcza w Sparcie, ale również w republice Platona (zob. jego Państwo). Mity, tragedie, eposy zawierają wiele scen zabijania dzieci, w tym przez kobiety, przez matki, czego przykładem Prokne i Filomela czy oszalała Medea: „dzika nienawiść kipi. Erynia wbrew woli/ rękę chwyta. Więc prowadź, idę z tobą, Gniewie!” (Seneka, Medea, 953954). Zemsta, nienawiść, odwet, zazdrość są najczęstszymi przyczynami

\footnotetext{
${ }^{3}$ W Antologii anegdoty antycznej, 1963, s. 28 radę Chilona przetłumaczono jako Czcij wiek sędziwy.

4 Tak poświadcza Ksenofont (430-355 p.n.e.) we Wspomnieniach o Sokratesie, co podaję za: Gajda 1989, 268.

5 O rodzinie greckiej i rzymskiej, w tym o porzucaniu dzieci, zob. Jurewicz, Winniczuk 1970, rozdz. I, II, VI.
} 
dzieciobójstwa w mitach. Przykłady matek morderczyń pokażą dokładniej i dobitniej, i dotkliwiej, co działo się z dziećmi w starożytności i jakie okoliczności wpływały na przykazanie czci lub szacunku dla rodziców.

Przytoczenia wraz z uwagami stanowią już niemal pełny kontekst do zrozumienia rozważanego przykazania. Sprowadzone do ograniczonej wersji Czcij ojca i matkę swoja być może odpowiada i wystarcza na co dzień dzisiejszemu chrześcijaninowi, ale nie wystarcza do tego, żeby pojąć lud i czasy, które je wydały, nie wystarcza do zrozumienia przeszłości i tradycji, zwłaszcza na lekcji języka polskiego. Oprócz tego badawczego, poznawczego zamiaru u współczesnego czytelnika występuje, tak jak u mnie, a u innych, np. uczniów, może wystąpić poczucie dysproporcji między karą a winą, np. śmierć za złorzeczenie rodzicom. Ta dzisiejsza wrażliwość różna od starożytnej stanowi jeden z powodów budowania poznawczego i emocjonalnego dystansu do niektórych składników tradycji.

\section{Nawiązania polskie}

O strasznym imieniu Pana, Boga twego pamiętał w Zwierciadle Mikołaj Rej, który tym samym dał dowód, że rozumiał o wiele więcej niż dzisiejszy czytelnik sprowadzający przykazanie do kilku pierwszych wyrazów. Tłumaczył szlachcicowi poczciwemu:

Rodzice miej w poczciwości. A gdyć Pan Bóg zasię pozdarzy przyjechać do domu twojego, miejże to na pilnej pieczy, abyś ni w czym nie był przykry rodzicom twoim, abyś je na wszem w poczciwości miał, takież i czeladce swojej to pilnie rozkazował. Abowiem wiesz, jaki srogi Pan na to zakład założyć raczył, powiedając, iż: „Miej w poczciwości rodzice twoje, chceszli długo żyw być na ziemi” $(\operatorname{Rej~1956,~360)6~}$.

Jahwe jako bóg zazdrosny i mściwy, zgodnie ze swoją naturą, ustanowił ciężki warunek: chceszli długo żyw być na ziemi, jak zresztą często w Starym Testamencie w różnych sytuacjach. I to jest wykładnia, sens, cel tego, co dzisiaj znane jest jedynie jako czcij ojca i matkę, a co ukrywa srogość. W powszechnie znanym okrojonym kształcie przykazanie za bardzo zmienia, a nawet traci sens, traci charakter (żydowski), moc, groźbę w nim tkwiącą. W skróconej wersji przejawia się nadmierne dostosowanie do czasów nowożytnych, do człowieka mającego inną wrażliwość, inne stosunki rodzinne, inne prawo i obyczaje. Takie okrojenie uznaję za mamiące i szkodliwe. Za sprawą Reja nakaz czci dla rodziców odzyskuje barwy właściwe starożydowskim czasom: nie miał on złudzeń, że srogi Pan na to zakład założyć raczył ...chceszli długo żyw być na ziemi. Dzisiaj o tym warunku nie wszyscy pamiętają, bo nie wszyscy czytają całe przykazanie - uważnie.

Europejska a wraz z nią polska pedagogika tak rodzinna, jak szkolna oparta była na czci wobec rodziców - zwłaszcza ojca jako reprezentanta

${ }^{6}$ Wyjątki ze Zwierciadła według wydania J. Czubka i J. Łosia, Kraków 1914. Zob. także w Rejowej Postylli wątki karania, posłuszeństwa, warunkowej łaski Boga. 
Boga na ziemi i w jego imieniu sprawującego władzę nad dziećmi - i karze jako narzędziu przyuczającym i wymuszającym tę cześć, wraz z posłuszeństwem, pokorą etc. Typowy pogląd wyraził Erazm Gliczner w Ksiązkach o wychowaniu dzieci w rozdziale VII Jako tego potrzeba, aby rodzicy syny swe karali, ale $z$ baczeniem, a nie $z$ wielkim gniewem (Gliczner 1956, 289296). Nawiązał do „dawnej i starej przypowieści” (biblijnej) o tym, że gdyby dzieci „z przyrodzenia dobroć a stateczność miłowały”, wtedy nie trzeba by było ich „karać albo rószczką wzbierać”, a ponieważ dzieci „są chłopiątka, łotrowie z początku, (...) z przyrodzenia złością, zuchwalstwem i rozpustą (...) zepsowane i zakażone są - potrzeba tego ukazuje, aby rodzicy z młodu one karali" (Gliczner 1956, 289-290). I nawet nie z własnej, ludzkiej woli, lecz „według rozkazania boskiego, który chce, aby rozpusty nie było. Tak jako On karze rodzaj ludzki, by ociec syny, tak rodzicy (...) syny swe ku chwale bożej a cnocie mają podczas przymuszać" (Gliczner 1956, 291). Ta chrześcijańska pedagogika, mimo że krytykowana w ciągu stuleci, zastępowana niereligijnymi pedagogiami, sama się przecież kompromitująca, trwa do dziś w ten, mocniejszy, czy inny, słabszy, sposób. Jak się wydaje, tradycję biblijnej pedagogiki, ojca popędliwego, ojca nieprzyjaciela własnego syna pokazuje Wojciech Kuczok w powieści Gnój. Widzimy takiego w Ksiażkach o wychowaniu, kiedy ich autor pisze o

ojcach dziwnych a popędliwych, którzy nic prawie dzieciam swym przejrzeć a przepuścić nie chcą, jedno ile by nie wejrzeli, tyle chłost i łazien zadają i palą. Drudzy zasię są tak okrutni, iż gdy co syn zawini, co jedno by mieli w ręku - bądź miecz, bądź kijec, bądź buławę - tedy tym, zapamiętawszy się, karzą tak, iż drugi syna zabije, drugi rani albo stłucze. Około czego każdy to obaczyć może, jeśli takiego ojca syn miłować ma, który mu więcej nieprzyjacielem jest niż ojcem (Gliczner $1956,294)$.

Owszem, na wszelki wypadek za autorytetami starożytności zaleca się „w karaniu obyczaj a porządek”, który na tym „zasadzon jest, aby rodzicy nie zapalonym gniewem ani popędliwą furyją albo też z jakim okrutnym a barzo srogim karanim a wzbieranim dzieci swych doglądali" (Gliczner 1956, 291-292). Wątek karania kończy się ponownym przywołaniem boskiego nakazodawcy:

iż Pan Bóg, gdy karze, czyni to więcej z miłości a łaski, nie iżby zatracił, ale aby nawrócił; tak też i rodzicy sprawować się mają; niech dzieci karzą - nie iżby je zabili albo jedli, ale aby z nich co dobrego mogło uróść, co by było ku czci i ku chwale Panu Bogu, tak Rzeczy Pospolitej krześcijańskiej, tudzież przyjacielom ku pociesze (Gliczner 1956, 296) ${ }^{7}$.

Niczego z tego krześcijańskiego karania nie da się dziś ocalić. Nie jest ono w ogóle potrzebne do tego, aby z dzieci co dobrego mogło uróść ku chwale Rzeczypospolitej i pociesze przyjaciół.

${ }^{7}$ Jedli ma znaczenie figuralne: jeść kogo albo siebie = niszczyć, gubić (Linde 1808, 890). 


\section{Lekcja}

Przykazanie czwarte nie powinno już pojawiać się w podręcznikach i na lekcjach w wersji skróconej i poza kontekstem, lecz tylko w całości i wraz z innymi przepisami prawa i wiadomościami o stosunkach rodzinnych tamtej epoki, dopiero po mniej więcej podobnym do niniejszego przejrzeniu, opracowaniu, przepracowaniu. Tak żeby sobie i uczniom oczu nie mydlić nieustannym cytowaniem wyuczonych przykazań przy braku dokładniejszego rozpoznania a nawet opacznym rozumieniu, jak w wypadku nie pożadaj żony bliźniego.

Warto również pozbyć się idealizującego i sentymentalnego ujęcia, gdyż te cechy zaciemniają, zacierają rzeczywiste stosunki w rodzinach żydowskich, rzeczywistą pozycję ojca i syna, rzeczywistą groźbę i strach, utrudniają zmierzanie do niefałszowania pewnego składnika tradycji europejskiej, do jej przezwyciężenia tam, gdzie się da. (To samo dotyczy ofiary Abrahama - również nierozpoznanej.)

Czcij... w wersji krótkiej ukrywa wszystkie sankcje, jakie są w wersjach dłuższych, a nawet i one czytane bez kontekstów, poza prawem i obyczajem starotestamentowym nie pokazują jeszcze wszystkiego: karania, chłosty, zależności syna, gwałtowności ojca i za nim stojącego Boga ojca, wszechwładzy nad dziećmi, niewoli, ich śmierci. Z kolei coraz powszechniejsze i będące całością szanuj ojca i matkę lub szanuj rodziców wydaje się właściwe dla naszych czasów, odpowiednie dla światopoglądu współczesnego człowieka coraz bardziej zeświecczonego.

Nie od dziś istnieje rozbieżność: kiedy dzisiejszy człowiek, zwłaszcza młody, wypowiada szanuj ojca i matke, ma co innego „w tyle głowy” i w tle wypowiedzi, niż kiedy wypowiada starożytne czcij ojca swego i matkę swoją. Między tym nowszym zdaniem a tym dawnym zachodzą już tylko powierzchowne podobieństwa, a cała reszta, tło kulturowe i prawne jest już w dużej mierze inna. Ta rozbieżność powinna być śrubą obrotową lekcyjnych poczynań zmierzających do wyzwalania się z kleszczów przeszłości, z mechanicznych skojarzeń. Czy lekcje polskiego o czwartym przykazaniu i w ogóle o dekalogowych tematach nie bywają bardziej katechetyczne niż katecheza? Nie będą takie, jeśli wyżej zebrany i opatrzony objaśnieniami materiał zostanie spożytkowany przez nauczyciela.

Zawartość tego szkicu łatwo przekształcić w lekcję o takim samym układzie: 1. wytworzenie sytuacji problemowej dzięki dostrzeżeniu, że istnieją dwie wersje przykazania: krótka i pełna, oraz różnicy w semantyce i w zakresie użycia między czcij (węższe) a szanuj (szersze użycie), 2. uważne czytanie przykazania czwartego w całości ze zwróceniem uwagi na jego drugą część abyśdługo żył, która wnosi niepokój a nawet nerwowość, przechodzącą w poczucie zagrożenia, kiedy 3. uczniowie poznają przewidziane żydowskim prawem i moralnością kary czyhające na syna za uchybienia czci rodziców i 4. kiedy zrozumieją, przeżyją sytuację (niedoszłego) 
zabijania syna przez ojca na przykładzie Izaaka i Abrahama, 5. poznanie eksplikacji przykazania czwartego przez Mikołaja Reja z dobitnie warunkowym chceszli długo żyw być na ziemi, rzuconym na pedagogiczną koncepcję pozwalającą na dotkliwe karanie syna w imię Boga (cytat z Glicznera s. 291 lub s. 296); jednocześnie uczniowie otrzymają dwa przykłady polskiej prozy z XVI wieku, niestety nieczęsto umieszczanej w podręcznikach; zwracam uwagę na staropolsko piękne i godne upowszechnienia „rodzice miej w poczciwości" u Reja, najlepszego polskiego interpretatora przykazania, i językowo ciekawe, ale pedagogicznie przebrzmiałe „niech dzieci karzą - nie iżby je zabili albo jedli, ale aby z nich co dobrego mogło uróść" u Glicznera; 6. na koniec fragment Gnoju Kuczoka - do dyskusji lub - przeciwnie - jako zamknięcie lekcji.

Mogą się przydać jeszcze inne polskie konteksty i kontynuacje: przykazanie czwarte w wersji średniowiecznej (zob. dekalogi w: Toć jest dziwne a nowe 1987, 35-38); staropolskie obyczaje, zachowania, przejawy czci dzieci wobec rodziców w literaturze i sztuce, np. pokłon, przyklęknięcie na kolano, całowanie ręki, co widać np. w Zemście i Panu Tadeuszu.

Przydadzą się też pytania, na które odpowiedzi dostarcza cały artykuł: Czy przykazanie w okrojonej postaci Czcij ojca i matkę zachowuje swój pierwotny sens, czy go wypacza? Czy w pierwotnej długiej postaci jest łagodne, miłe, czy groźne? Czy takie zniekształcenie przykazania wraz z innymi zniekształceniami innych przykazań i innych fragmentów Starego Testamentu nie powodują, że sens tego całego zbioru też się wypacza, że nie znamy go dobrze, prawdziwie? Co sądzisz o typowych wtedy karach dla dzieci: ojciec mógł sprzedać córkę jako niewolnicę, przymusić ją do nierządu, krnąbrnego syna doprowadzić do ukamienowania przy pomocy starszyzny miasta, wierzyciel miał prawo odebrać dłużnikowi dzieci, wziąć je jako niewolników za niespłacony dług? Jak one świadczą o miejscu i roli dzieci w tym społeczeństwie? Wszystkie kary są w imieniu Boga (Jahwe) i z jego rozkazu. Jakie zatem ma cechy ten bóg? Dokładniej: jakie cechy ma społeczność, która wyobraziła sobie takiego boga i takie kary? Oczywiste wydaje się wykonane na początku artykułu polecenie: Wskaż różnice między Czcij ojca i matkę a Szanuj ojca i matkę.

Poprzestawanie w podręcznikach i lekcjach na wersji $c z c i j$, tej najprostszej, świadczy o pójściu na łatwiznę, o utrwalaniu jedynie sformułowania znanego już z katechezy. A przecież nie do tego służą podręczniki i lekcje języka polskiego. Więc aby zaszło poważne, właściwe uczenie się i nauczanie, potrzebne są dłuższe wersje przykazania, wiadomości o nim, konteksty z epoki i późniejsze, ich krytyczna analiza, nieufna interpretacja itd. Skierowanie uwagi na abyś... żył... pozwala odkryć zwyczaje, prawa, wolność, posłuszeństwo, karanie, wiedzę o plemieniu, o kulturze, o Starym Testamencie niesprowadzoną do komunałów. Skoro zestaw ksiąg starotestamentowych i wszystkie biblia składające się na Biblię są tak ważne, to 
trzeba mieć nieco więcej wiedzy o niej, o treści, o zwyczajach, o stosunkach międzyludzkich w niej zapisanych.

\section{Wymaganie naturalnego szacunku dzieci dla rodziców}

W Starym Testamencie wiele razy mówi się o karaniu dzieci, zwłaszcza syna, przez ojca i w ogóle rodziców. Wszystko jest powiedziane z punktu widzenia ojca i ponad nim stojącego Jahwe. Nie ma punktu widzenia dziecka i nie mogło być w tamtych czasach, z tego też powodu - między innymi - te księgi są tak obce wraz z poglądami, przykazaniami itp. Czyż nie dziwi ograniczoność czwartego przykazania niezrównoważonego, nieposzerzonego o nakaz dbania o dzieci, wychowywania ich? Nie dziwi w warunkach bytowania koczowniczego plemienia, wędrującego od oazy do oazy, poganiającego stada owiec i kóz. Prawa dziecka? Tego nie było w Starym Testamencie, nie mogło być. Jednak stopniowo wraz z wyzwalaniem się spod władzy kościelnej od początków epoki nowożytnej, potem wyraźnie, dobitnie w XVIII wieku (np. Rousseau) dziecko zostaje dostrzeżone, aby w końcu wiek XX zyskał miano „stulecia dziecka”. (Ale też czy nie za daleko ten pajdocentryzm zaszedł?)

Rozróżnienie Czcij bogów, szanuj rodziców wydaje mi się przydatne i trafne dzisiaj. Czcij niech obsługuje religię, a w szkole widzę wyłącznie niereligijne szanuj lub kochaj (jak chcą niektórzy, bardziej uczuciowi) jako pojęcia bliższe dzisiejszym ludziom, które nie mają już zbyt wiele wspólnego z hebrajskim przykazaniem a zwłaszcza z jego zapleczem społecznym i światopoglądowym, tak się zmieniły pojęcia, postawy, zwyczaje, ludzie, kultura. Lekcje polskiego są po to, by dostarczać wiedzy o tym zapleczu i uświadamiać odległość i różnice między epokami, powinny też zerwać z automatyzmem skojarzeń wyniesionym z religii, aby nie stały się drugą, a przy tym ukrytą, katechezą, aby nie przyuczały wyobraźni i umysłów do powierzchownego a nawet fałszującego związku ze starotestamentowym nakazem. Właśnie wiedza o zapleczu obyczajowym i prawnym uchroni przed uległością pozorowi bliskości, tym bardziej gdy przywoła się pajdocentryczne skłonności naszych czasów. Nasze wyobrażenia i wyrażenia o szacunku dla rodziców powinny być jak najbardziej współczesne myślowo i językowo; szanuj jako norma wypracowana przez ludzi dla ludzi o ludziach z ludzką sankcją, prawem. Takie ludzkie, ziemskie, współczesne szanuj (bez uzależnienia go od abyś długo żył na ziemi) nie wzięło się ze Starego Testamentu ani w ogóle z Biblii, lecz znała je każda grupa rodzinna gdziekolwiek na Ziemi i bez względu na to, czy zostało zapisane w tej czy innej „świętej” księdze. Bliższe nam są raczej świeckie rozważania myślicieli oświeceniowych o prawie natury, uznanej za grzeszną we wspomnianych księgach. Wolter ujął rzecz tak: „Prawem naturalnym jest to, co natura przykazuje wszystkim ludziom. Wychowałeś dziecko, winno ci ono szacunek, jako swemu ojcu, wdzięczność, jako swemu dobroczyńcy" (Wolter 1956, 32). 
Myślowo i językowo wyraża nasze czasy „wymaganie naturalnego szacunku dzieci dla rodziców”, które przegląda się w szacunku rodziców dla dzieci.

\section{Bibliografia:}

Antologia anegdoty antycznej. Historyjki budujące i niebudujące $z$ autorów greckich i rzymskich, 1963, zebrał, przełożył i ułożył J. Łanowski, rysunkami dopełnił T. Łowicki, Wrocław.

Antologia literatury polskiego średniowiecza, 1987, Jelicz A. (oprac.), Warszawa.

Biblia to jest pismo święte Starego i Nowego Testamentu, 1982, nowy przekład z języków hebrajskiego i greckiego opracowany przez Komisję Przekładu Pisma Świętego, wyd. X, Warszawa.

Chouraqui André, 2002, Dziesięć przykazań dzisiaj, Gościniak A., Karwowska E. (przeł.), Warszawa.

Gajda Janina, 1989, Sofiści, Warszawa.

Gliczner Erazm, 1956, Ksią̇ki o wychowaniu dzieci bardzo dobre, pożyteczne i potrzebne, fragm. w: Wybór pism pedagogicznych Polski doby odrodzenia, Skoczek J. (oprac.), Wrocław, s. 271-319.

Hempel Jan, 1956, Ewangelie. Dziesięcioro przykazań, Warszawa.

Jurewicz Oktawian, Winniczuk Lidia, 1970, Starożytni Grecy i Rzymianie w życiu prywatnym i państwowym, Warszawa.

Krzyżanowski Julian, 1960, Mądrej głowie dość dwie słowie, tom I, Trzy centurie przysłów polskich, wyd. drugie, Warszawa, s. 213-214.

Laertios Diogenes, 1968, Żywoty i poglądy słynnych filozofów, przekład zbiorowy, Krońska I. (oprac. przekładu, przypisy i skorowidz), Leśniak K. (wstęp), Warszawa.

Linde Samuel B., 1808, Słownik języka polskiego, tom I, cz. G-L, Warszawa.

Metzger Bruce M., Coogan Michael D. (red.), Słownik wiedzy biblijnej, konsultacja wydania polskiego W. Chrostowski, wyd. IV, Warszawa.

Ravasi Gianfranco, 2003, Przykazania w Piśmie Świętym i w sztuce, Stopa K. (przeł. z jęz. włoskiego), Kielce.

Rej Mikołaj, 1956, Zwierciadło (wyjątki), w: Wybór pism pedagogicznych Polski doby odrodzenia, Skoczek J. (oprac.), Wrocław.

Wolter, 1956, Traktat o tolerancji napisany z powodu śmierci Jana Calasa, Ryłko Z. i Sowiński A. (przeł.), Ryłko Z. (posłowiem i przypisami opatrzył), Warszawa.

Wright David F., 2004, Rodzina, w: Metzger B. M., Coogan M. D. (red.), Słownik wiedzy biblijnej, konsultacja wydania polskiego W. Chrostowski, wyd. IV, Warszawa.

Wydra Wiesław, 1973, Polskie dekalogi średniowieczne, Warszawa.

„Zeszyty Karmelitańskie”, 2014, nr 2, Poznań. 


\section{O Autorze:}

Kordian Bakuła, pisze o dydaktyce języka i literatury, redaktor naczelny „Kształcenia Językowego” (20 pkt), autor książki Mówione ₹ pisane: komunikacja, język, tekst (2008). 